\title{
Awards and the Pursuit of Happiness
}

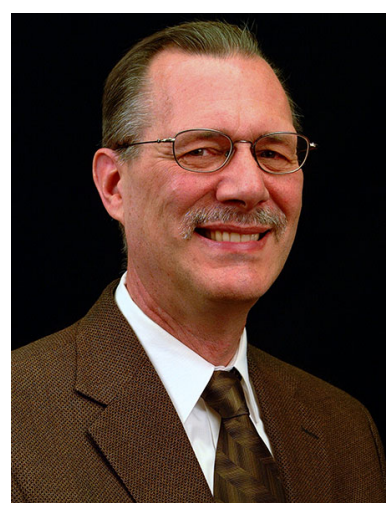

John Morral
I was happy to learn that Dr. Ursula Kattner will receive the 2016 J. Willard Gibbs Phase Equilibria Award from ASM International. She is an outstanding associate editor and a skilled reviewer for our Journal. When policy questions arise, she is always in the discussion because of her broad knowledge and wise opinions. However, this is not specifically an editorial about Dr. Kattner. This is an editorial about awards and happiness.

After learning of the award, I wondered "who else will be happy upon learning she won the award" and "of those happy people, who will be happiest." Actually, I already had a theory about the answer to the last question.

Certainly her family, friends, and colleagues at NIST will be happy about the award. People at the Journal of Phase Equilibria and Diffusion have reasons to be happy, too. Also, other people who know her through contacts at meetings or familiarity with her work might feel a pleasant glow of happiness learning of her success.

However who in this group will be the happiest? If you think the happiest person is always the one who receives the award, then you are thinking as I did 30 years ago. It was at this point in my career that I decided to learn more about the award process and about people who won awards. As a first step, I began nominating deserving associates. That introduced me to the world of available awards, and most importantly to the requirements for receiving awards. In time I received an award myself, leading to my being invited to serve on award committees.

Award committees are like secret societies, because member names are held in confidence and members are sworn not to reveal their proceedings. You have to be on award committees to know how they work, an especially valuable experience when trying to understand why an exceptional nomination fails.

But again, who is the happiest? Is it a person's parent or supervisor at work? Is it a contract monitor at NSF or another agency that supported the awardees' research? Is it a teacher who learns a former student is receiving a well-deserved recognition? Examples of each can be found, but my hypothesis is that all are outliers. In my own experience, the happiest person is the one who prepares the winning nomination. That person can revel in both the success of the nominee and in his or her own success in preparing the nomination. Nominators get a double dose of happiness. That is one reason I have nominated people for the last 30 years. It was driven by a personal pursuit of happiness.

Perhaps the nominator is not normally the happiest person. That is just a theory. However if you have never nominated a colleague for an award, now would be a good time to start. By doing so you can test the theory, learn more about how awards are won, and encourage a person in your profession. You will be happy you did, as will the person you nominate.

\author{
John Morral \\ The Ohio State University, Columbus \\ OH, USA \\ E-mail: jemorral@gmail.com
}

